\title{
Effect of insulin-like growth factor binding protein-1 on integrin signalling and the induction of apoptosis in human breast cancer cells
}

\section{M Perks, P V Newcomb, M R Norman ${ }^{1}$ and J M P Holly}

Division of Surgery, Department of Hospital Medicine, Level 7, Bristol Royal Infirmary, Bristol, BS2 8HW, UK

${ }^{1}$ Department of Medicine, Upper Maudlin Street, Bristol Royal Infirmary, Bristol, BS2 8HW, UK

(Requests for offprints should be addressed to C M Perks)

\begin{abstract}
Interaction of epithelial cells with the extracellular matrix is mediated through integrin receptors, which transmit signals regulating cell growth, differentiation and death. Occupation of these receptors, via Arg-Gly-Asp (RGD) recognition sequences, leads to activation of focal adhesion kinase (FAK).

We treated human breast cancer cell lines with RGD-containing peptides, which can disrupt integrin attachment, and investigated alterations in FAK phosphorylation, cell detachment and death. Cells grown in vitro were treated with insulin-like growth factor-binding protein-1 (IGFBP-1) and a small, synthetic RGD-containing peptide (GlyArg-Gly-Asp-Thr-Pro) and its negative control peptide RGE (Arg-Gly-Glu-Ser) for either $30 \mathrm{~min}$
\end{abstract}

followed by immunoprecipitation of cell lysates with anti-phosphotyrosine and Western immunoblotting with anti-FAK or for $24 \mathrm{~h}$ followed by cell counting, immunocytochemistry and flow cytometry.

Both IGFBP-1 (0-800 ng/ml) and the synthetic RGD-containing peptide $(1-100 \mu \mathrm{g} / \mathrm{ml})$ caused significant dephosphorylation of FAK. Furthermore, after $24 \mathrm{~h}$ both peptides caused detachment from the matrix and the induction of apoptosis.

We conclude from these data that IGFBP-1 can interact with integrin receptors to induce FAK dephosphorylation and subsequently influence attachment and cell death.

Fournal of Molecular Endocrinology (1999) 22, 141-150

\section{INTRODUCTION}

The normal growth of cells generally requires attachment to a substrate and the presence of growth factors (Ingber 1990). Cells which become transformed or malignant are characterised by the ability to undergo anchorage-independent growth (Freedman \& Shin 1974, Tucker et al. 1981). Cell adhesion to the extracellular matrix (ECM) in vivo is mediated by integrin receptors. These bind to matrix proteins outside the cell and associate with cytoskeletal proteins within the cell. ECMs are composed of several macromolecules including fibronectin, laminin, collagens and proteoglycans (Ruoslahti \& Pierschbacher 1987). A number of these adhesive proteins, for example fibronectin (Pierschbacher \& Ruoslahti 1984), contain the three amino acid sequence Arg-Gly-Asp (RGD), which is specifically recognised by corresponding integrin receptors (Ruoslahti \& Pierschbacher 1987).
The binding of integrins to the ECM initiates assembly of actin microfilaments and the accumulation of numerous different proteins, including signalling molecules, integrins and components of the cytoskeleton, into structures called focal adhesions (Burridge et al. 1988). A number of these proteins, including focal adhesion kinase (FAK), paxillin (Burridge et al. 1992) and tensin (Bockholt \& Burridge 1993), are tyrosine phosphorylated upon integrin ligation, suggesting a role for these proteins in integrin signalling. Specifically, integrin-dependent signals have been shown to modulate the control of growth (Giancotti \& Ruoslahti 1990) and cell survival (Frisch \& Francis 1994).

Maintenance of integrin linkages is essential for cell adhesion. It has been demonstrated previously that disruption of these attachments, via addition of antibodies or peptides, can induce cells to detach from the substratum (Knudson et al. 1981, 
Hayman et al. 1985) with a resultant induction of programmed cell death.

Insulin-like growth factor binding protein-1 (IGFBP-1) belongs to a family of six closely related proteins (IGFBP-1 to -6) that are known to modulate the actions of insulin-like growth factors (IGFs) (Shimasaki et al. 1991, Oh et al. 1996). These proteins bind IGF-I and -II with high affinity, thereby modulating their actions on target cells (Clemmons 1992). However, evidence now suggests that these binding proteins may be able to exert IGFindependent effects. Specifically, IGFBP-1, which contains an RGD integrin recognition sequence (Brewer et al. 1988, Hynes 1992), can stimulate cell migration in $\mathrm{CHO}$ cells. This action of IGFBP-1 was demonstrated to be specifically via binding to the $\alpha_{5} \beta_{1}$ integrin receptor and is independent of the IGFs (Jones et al. 1993). IGFBP-1 is expressed in a strictly tissue-specific manner, being normally restricted to the liver and a small number of other tissues, including decidualised endometrium (Julkunen et al. 1988), the ovary (Suikkari et al. 1989) and regenerating liver (Mohn et al.1991), all of which exhibit high rates of tissue remodelling.

However, it has also been demonstrated that IGFBP-1 is expressed in the breast both in vitro (Clemmons et al. 1990) and in vivo (Pekonen et al. 1992). IGFBP-1 mRNA expression increased in human breast tumours in comparison to their adjacent normal tissue. The upregulation of IGFBP-1 was associated with the malignant transformation of breast tissue (Pekonen et al. 1992).

Therefore, we chose to study the effects of RGD-containing peptides, including IGFBP-1, on FAK phosphorylation, cell attachment and death in our human breast cancer cell lines, since IGFBP-1 may have a significant pathological role in this tissue. Furthermore, one of our lines, Hs578T, is an ideal model in which to study IGF-independent effects of this binding protein, since it is nonresponsive to IGFs and lacks a functional IGF receptor. In fact, we have shown previously in this cell line that IGFBP-3 could predispose cells to programmed cell death in an IGF-independent manner (Gill et al. 1997). We also studied three additional breast cancer cell lines, MCF-7, T47D and ZR-75-1, which are IGF-responsive.

The results of this study provide us with evidence to suggest that IGFBP-1 is capable of eliciting integrin-mediated IGF-independent cellular effects.

\section{MATERIALS AND METHODS}

Human IGFBP-1 peptide was a gift from Dr J Cox, Synergen Inc. (Boulder, CO, USA). The RGD- containing synthetic peptide (Gly-Arg-Gly-AspThr-Pro) together with its negative control peptide, RGE (Arg-Gly-Glu-Ser) were bought from Sigma Chemical Co., Poole, Dorset, UK. All other reagents were purchased from Sigma Chemical Co. or Merck Sharp and Dohme Ltd (Hoddesdon, Herts, UK) unless otherwise stated.

\section{Cell culture}

The human breast cancer cell lines T47D, Hs578T, MCF-7 and ZR-75-1 were purchased from ECACC (Porton Down, Wilts, UK) and grown in a humidified $5 \% \mathrm{CO}_{2}$ atmosphere at $37^{\circ} \mathrm{C}$. They were cultured in Dulbecco's modified Eagle's medium (DMEM) with glutamax-1, Minimum Essential Medium (MEM), Eagle's medium and RPMI 1640 medium respectively supplemented with $10 \%$ foetal calf serum (Advanced Protein Products Ltd, Brierley Hill, West Midlands, UK), penicillin $(5000 \mathrm{IU} / \mathrm{ml})$, streptomycin $(5 \mathrm{mg} / \mathrm{ml})$ and L-glutamine $(2 \mathrm{mM})$.

\section{Immunoprecipitation and Western immunoblotting}

Cells $\left(1 \times 10^{6}\right)$ were grown to $80 \%$ confluence in $90 \mathrm{~mm}$ dishes (Nunclon, Rochester, NY, USA) and then washed twice with PBS. The growth medium was replaced with serum-free Dulbecco's MEM and Ham's nutrient mix F-12 buffered with Hepes and supplemented with sodium bicarbonate $(0 \cdot 12 \%)$, BSA $(0 \cdot 2 \mathrm{mg} / \mathrm{ml})$ and transferrin $(0 \cdot 01 \mathrm{mg} / \mathrm{ml})$ (SFM) for $24 \mathrm{~h}$. Cells were treated, incubated at $37^{\circ} \mathrm{C}$ for $30 \mathrm{~min}$ and then lysed on ice for $10 \mathrm{~min}$ $(1 \mathrm{ml} ; 10 \mathrm{mM}$ Tris- $\mathrm{HCl}, 5 \mathrm{mM}$ EDTA, $50 \mathrm{mM}$ $\mathrm{NaCl}, \quad 30 \mathrm{mM}$ sodium pyrophosphate, $50 \mathrm{mM}$ sodium fluoride, $100 \mu \mathrm{M}$ sodium orthovanadate, $1 \%$ Triton, $1 \mathrm{mM}$ phenylmethylsulphonyl fluoride; $\mathrm{pH}$ $7 \cdot 6)$. Lysates were then centrifuged at $14000 \mathrm{~g}$ for $15 \mathrm{~min}$ at $4{ }^{\circ} \mathrm{C}$. The supernatant fractions were incubated at $4{ }^{\circ} \mathrm{C}$ with anti-phosphotyrosine antibody $(4 \mu \mathrm{g}$; Upstate Biotechnology, Lake Placid, $\mathrm{NY}$, USA) for $2 \mathrm{~h}$, goat anti-mouse $\operatorname{IgG}(5 \mu \mathrm{l}$; Calbiochem, Beeston, Nottingham, UK) for $1 \mathrm{~h}$ and then $25 \mu$ protein-A-Sepharose beads (Calbiochem) for $1 \mathrm{~h}$. The samples were washed three times with lysis buffer $(500 \mu \mathrm{l})$, centrifuged at $14000 \mathrm{~g}$ for $3 \mathrm{~min}$ and the supernatant removed. Laemmli loading buffer $(2 \times)$ was added and proteins were separated by $8 \%$ SDS-PAGE and then transferred onto a nylon membrane. Non-specific binding sites were blocked by washing the membranes in $5 \%$ milk and then they were probed with anti-FAK $(1 \mu \mathrm{g} / \mathrm{ml}$; Upstate Biotechnology) overnight. Following the removal of excess unbound antibody, an anti-mouse 
antibody conjugated to peroxidase $(1: 2000)$ was added for $1 \mathrm{~h}$. Binding of the peroxidase was visualised by enhanced chemiluminescence according to the manufacturer's instructions (Amersham International, Amersham, Bucks, UK). Optical density measurements were determined using a scanning densitometer (Bio-Rad, Hemel Hemstead, Herts, UK) and analysed using Molecular Analyst software (Biorad).

\section{Cell counting}

Aliquots of cells $(50 \mu \mathrm{l})$ were loaded onto a haemocytometer and the total cell number was determined.

\section{Flow cytometry}

This technique was used to assess the amount of apoptosis in a given sample. Apoptotic cells have a lower DNA stainability than normal cells and appear as a pre-G1 peak on a DNA cell cycle histogram. Cells $\left(1-2 \times 10^{6}\right)$ were washed in PBS and fixed for $30 \mathrm{~min}$ by the addition of $70 \%$ ethanol $(1 \mathrm{ml})$. Cells were pelleted $(1600 \mathrm{~g} ; 5 \mathrm{~min})$ and washed three times with PBS. The supernatant was removed and the cells were resuspended in reaction buffer (propidium iodide, $0.05 \mathrm{mg} / \mathrm{ml}$; sodium citrate, $0 \cdot 1 \%$; RNAse A, $0.02 \mathrm{mg} / \mathrm{ml}$; NP-40, $0 \cdot 3 \%$; $\mathrm{pH} 8.3$ ) vortexed and incubated at $4{ }^{\circ} \mathrm{C}$ for $30 \mathrm{~min}$. All cells were then measured on a FACSCALIBUR flow cytometer (Becton Dickinson, Cowley, Oxford, $\mathrm{UK})$ with an argon laser at $488 \mathrm{~nm}$ for excitation and analysed using Cell Quest (Becton Dickinson).

\section{MTT assay}

MTT reagent (3-(4,5-dimethylthiazol-2-yl)-2,5diphenyltetrazolium bromide; Thiazolyl blue) is converted into a coloured water-insoluble formazan salt by the metabolic activity of viable cells and can be used as a crude measure of cell viability. Cells were seeded at $5 \times 10^{4} / \mathrm{ml}(150 \mu$ l growth medium $)$ in 96-well plates and allowed to grow for $24 \mathrm{~h}$. Growth medium was replaced with SFM $(100 \mu \mathrm{l})$ $24 \mathrm{~h}$ prior to the assay. MTT reagent $(7.5 \mathrm{mg} / \mathrm{ml})$ in PBS was added to the cells $(10 \mu \mathrm{l} /$ well $)$ and the cultures were incubated for $30 \mathrm{~min}$ at $37^{\circ} \mathrm{C}$. The reaction was stopped by the addition of acidified Triton buffer $(0 \cdot 1 \mathrm{M} \mathrm{HCl}, 10 \%$ (v/v) Triton X-100; $50 \mu \mathrm{l} /$ well) and the tetrazolium crystals were dissolved by mixing on a plate shaker for $20 \mathrm{~min}$ at room temperature. The samples were measured on a Bio-Rad 450 plate reader at a test wavelength of $595 \mathrm{~nm}$ and a reference wavelength of $650 \mathrm{~nm}$. Results, which are expressed as a percentage opti- cal density of SFM controls, represent the mean \pm S.E.M. of five wells from one experiment which is representative of experiments repeated at least three times.

\section{Morphological appearance}

To determine that IGFBP-1-induced cell death gave rise to the classical morphological features associated with apoptosis, aliquots of treated and untreated cells were cytospun and stained with Wright's stain in an automated stainer (Lillie 1977). Photomicrographs of the cells were taken under oil immersion at a magnification of $\times 100$.

\section{Immunocytochemistry}

Cells were cytospun $\left(150 \mu \mathrm{l} ; 5 \times 10^{5} / \mathrm{ml}\right)$ onto amino propyl triexothy silane-coated slides, fixed in cold acetone for $10 \mathrm{~min}$ and left to dry at room temperature for $10 \mathrm{~min}$. Cells were incubated with hydrogen peroxide $(0 \cdot 6 \%$ in methanol) for $15 \mathrm{~min}$, washed three times in Tris-buffered saline (TBS) for $5 \mathrm{~min}$ and incubated with $20 \%$ normal rabbit serum in TBS for $30 \mathrm{~min}$. Serum was removed and cells were incubated with antibodies (anti-human integrin $\alpha 5 \mathrm{IgG}, 5.8 \mu \mathrm{g} / \mathrm{ml}$; anti-human $\beta 1$ integrin $\mathrm{IgG}, 10 \mu \mathrm{g} / \mathrm{ml})$ at $4{ }^{\circ} \mathrm{C}$ overnight. Cells were then washed three times with TBS for $5 \mathrm{~min}$ and incubated with biotinylated rabbit anti-mouse $\operatorname{IgG}$ (1:300 in TBS) for $30 \mathrm{~min}$. After a further three washes in TBS, cells were incubated with streptavidin-biotin complex $(30 \mathrm{~min})$ followed by three TBS washes for $5 \mathrm{~min}$. Cells were then incubated with 3,3'-diaminobenzidene tetrahydrochloride for $10 \mathrm{~min}$ prior to counterstaining with Mayer's haematoxylin.

\section{Statistical analysis}

The data were analysed using the Microsoft Excel 4.0a software package. Significance was determined using Student's $t$-test. A statistically significant difference was considered to be present at $P<0 \cdot 05$.

\section{RESULTS}

\section{Measurement of FAK phosphorylation in cells treated with RGD-containing peptides over $30 \mathrm{~min}$}

The RGD-containing peptides caused significant dose-dependent decreases in the phosphorylation of FAK in the T47D cells (Fig. 1A and C). It is important to note that no cell detachment was 
A

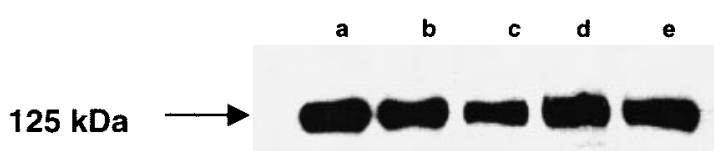

B

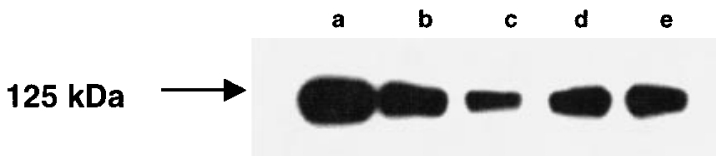

C

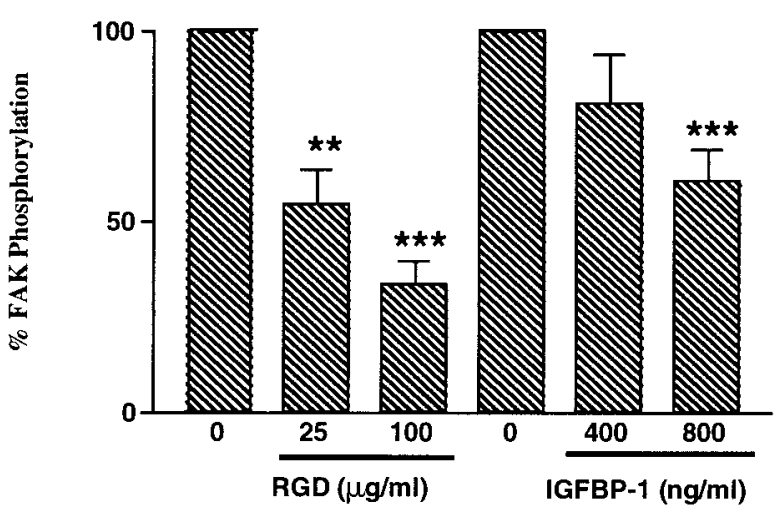

D

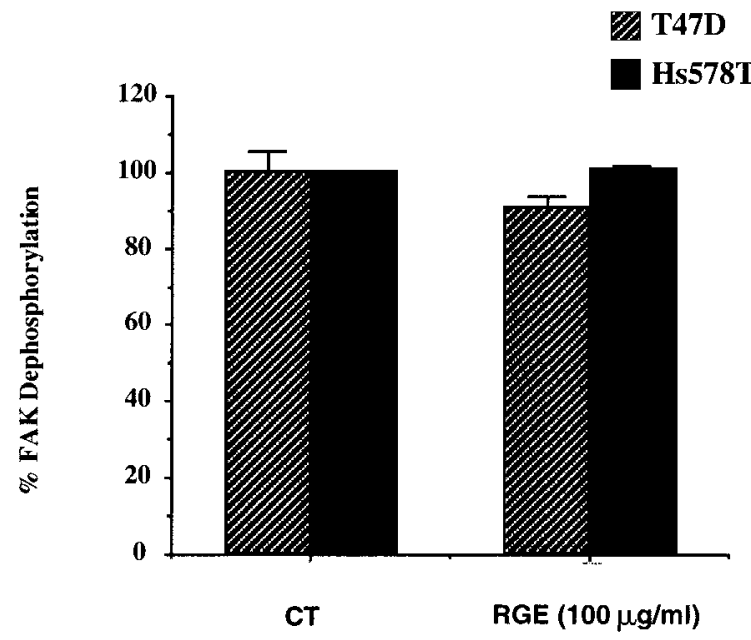

evident after $30 \mathrm{~min}$ treatment and no significant differences were found between the total protein concentrations of the individual plates. The synthetic RGD-containing peptide (Fig. 1A and C) reduced FAK phosphorylation significantly by $45.7 \%(P<0.01)$ and $66.5 \%(P<0.001)$ at 25 and $100 \mu \mathrm{g} / \mathrm{ml}$ respectively relative to control values. This reduction in FAK phosphorylation was also evident in the T47Ds after treatment with IGFBP-1 (Fig. 1A and C) at $400 \mathrm{ng} / \mathrm{ml}(19 \cdot 1 \%)$, becoming significant at $800 \mathrm{ng} / \mathrm{ml}(39 \cdot 4 \% ; P<0.001)$. We also showed that IGFBP-1 and the synthetic RGDcontaining peptide can similarly decrease FAK phosphorylation in another breast cancer cell line, Hs578T (Fig. 1B). The RGD-containing peptide reduced FAK phosphorylation by 31.5 and $62 \%$ at 25 and $100 \mu \mathrm{g} / \mathrm{ml}$ respectively. Similarly, IGFBP-1 was also able to induce the dephosphorylation of FAK in this cell line by 33.2 and $35 \%$ at 400 and $800 \mathrm{ng} / \mathrm{ml}$ respectively. The control synthetic peptide (RGE) had no significant effects on FAK phosphorylation in either cell line (Fig. 1D).

\section{Measurement of detached cells treated with RGD-containing peptides for $24 \mathrm{~h}$}

Data demonstrated that treatment with both the RGD-containing synthetic peptide and IGFBP-1 induced cells to detach from the plate over $24 \mathrm{~h}$ in T47D cultures (Fig. 2A and B). The RGDcontaining synthetic peptide (Fig. 2A; $100 \mu \mathrm{g} / \mathrm{ml}$ ) caused a significant $(P<0 \cdot 01)$ increase $(35 \cdot 3 \%)$ in the

FIGURE 1. Effects of a synthetic RGD-containing peptide $(0-100 \mu \mathrm{g} / \mathrm{ml})$ and IGFBP-1 $(0-800 \mathrm{ng} / \mathrm{ml})$ on FAK phosphorylation in T47D and Hs578T cells after treatment for $30 \mathrm{~min}$. Cells were plated in $90 \mathrm{~mm}$ Petri dishes, grown to $80 \%$ confluence and switched to SFM for $24 \mathrm{~h}$ prior to treatment. FAK phosphorylation was assessed by immunoprecipitation and Western immunoblotting as outlined in Materials and Methods. (A and B) Show representative Western immunoblots of T47D and Hs578T cells respectively; a=untreated cells, b=RGD $(25 \mu \mathrm{g} / \mathrm{ml})$, c=RGD $(100 \mu \mathrm{g} / \mathrm{ml})$, $\mathrm{d}=\mathrm{IGFBP}-1(400 \mathrm{ng} / \mathrm{ml})$ and $\mathrm{e}=\mathrm{IGFBP}-1(800 \mathrm{ng} / \mathrm{ml})$. (C) Optical density measurements of FAK

phosphorylation from Western immunoblots following immunoprecipitation in T47D cells. Results represent the mean \pm S.E.M. of experiments performed at least three times, where $* * * P<0 \cdot 001$ and $* * P<0 \cdot 01$. (D) Optical density measurements of FAK phosphorylation from Western immunoblots following immunoprecipitation in T47D and Hs578T cells after treatment with the control RGD peptide (RGE) in comparison to untreated control (CT) cells for $30 \mathrm{~min}$. Results represent the mean \pm S.E.M. of experiments performed at least three times. 


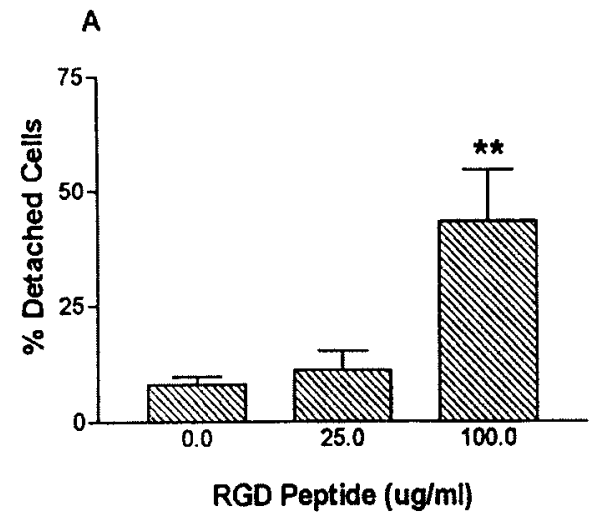

B

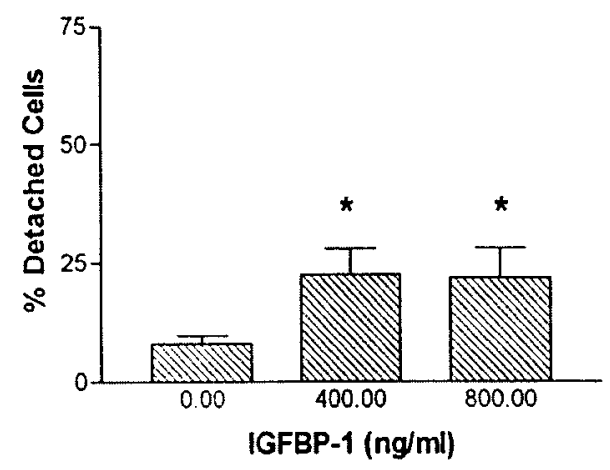

C

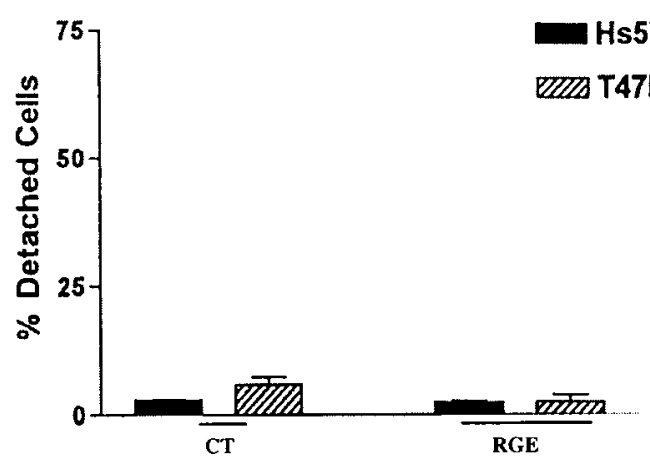

FIGURE 2. Measurement of detached cells by counting T47D cells treated with a synthetic RGD-containing peptide (A) or IGFBP-1 (B), and Hs578T and T47D cells treated with the RGD-control peptide (C) for $24 \mathrm{~h}$. Cells were grown in six-well plates, allowed to settle and switched to SFM for $24 \mathrm{~h}$ prior to treatment. Cells were incubated with either (A) a synthetic RGD-containing peptide $(0-100 \mu \mathrm{g} / \mathrm{ml})$, (B) IGFBP-1 $(0-800 \mathrm{ng} / \mathrm{ml})$ or (C) RGD-control peptide, RGE $(100 \mu \mathrm{g} / \mathrm{ml})$ for a further $24 \mathrm{~h}$. Cell number was assessed using a haemocytometer as described in Materials and Methods. Results represent the mean \pm s.E.M. of three wells from experiments repeated at least three times, where $* * P<0 \cdot 01$ and $* P<0 \cdot 05$. CT, control. number of detached cells in comparison to untreated cells. Similarly, IGFBP-1 (Fig. 2B; 400 and $800 \mathrm{ng} / \mathrm{ml})$ also caused significant $(P<0 \cdot 05)$ increases in detached cells at both doses tested $(14 \cdot 5$ and $13 \cdot 8 \%$ respectively) in comparison to control cells. Similarly, in the Hs578T cell line the RGD-containing peptide caused a 2.5 and $10 \%$ increase in the number of detached cells in comparison to untreated cells at 25 and $100 \mu \mathrm{g} / \mathrm{ml}$ respectively. Likewise, IGFBP-1 (400 and $800 \mathrm{ng} /$ $\mathrm{ml}$ ) also caused increases in detached cells in this cell line at both doses tested (9 and 6.7\% respectively). The control synthetic peptide (RGE) had no significant effects on cell detachment in either cell line (Fig. 2C).

Flow cytometric analysis of cells treated with RGD-containing synthetic peptides for $24 \mathrm{~h}$

Results showed that treatment with both the RGD-containing synthetic peptide and IGFBP-1 induced apoptosis after treatment for $24 \mathrm{~h}$ in T47D cells (Fig. 3A and B). Pre-G1 values significantly increased $(6 \cdot 7 \% ; P<0 \cdot 01)$ over control values after treatment with $100 \mu \mathrm{g} / \mathrm{ml}$ synthetic RGDcontaining peptide (Fig. 3A). Similarly, IGFBP-1 (Fig. 3B; 400 and $800 \mathrm{ng} / \mathrm{ml}$ ) also caused significant increases $(2.8$ and $3.2 \% ; P<0.05)$ in the extent of apoptosis relative to untreated samples. Morphological analysis also indicated classical features associated with apoptosis in the T47D cells after IGFBP-1 treatment (Fig. 3C and D). Cell shrinkage, cytoplasmic condensation and loss of nuclear membrane integrity were evident.

The effects of the RGD-containing peptide and IGFBP-1 in the Hs578T cell line were also comparable to data in the T47D cells. The RGD-containing peptide $(25$ and $100 \mu \mathrm{g} / \mathrm{ml})$ caused increases in the rate of apoptosis relative to control values $(3 \cdot 2$ and $17.9 \%$ respectively) as did IGFBP-1 (400 and $800 \mathrm{ng} / \mathrm{ml}$ ) at $1 \cdot 2$ and $4 \cdot 6 \%$ respectively.

We also demonstrated, using the MTT assay, which is a crude measure of cell viability, that the synthetic RGD-containing peptide had differential effects on cell survival depending on cell type, with the Hs578T cells being the most sensitive (Fig. 4).

\section{Localisation of $\alpha_{5}$ and $\beta_{1}$ integrin subunits by immunocytochemistry}

We demonstrated using immunocytochemistry that the cell lines T47D and Hs578T stained positively for $\alpha_{5}$ and $\beta_{1}$ integrin subunits. These are the components of the $\alpha_{5} \beta_{1}$ fibronectin receptor, which 
A

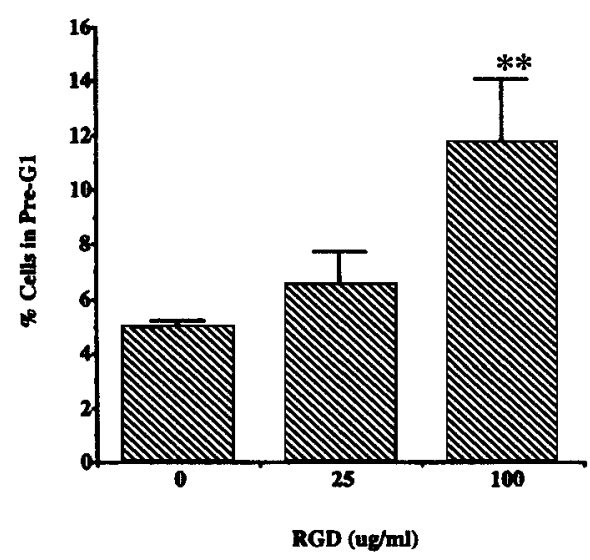

B

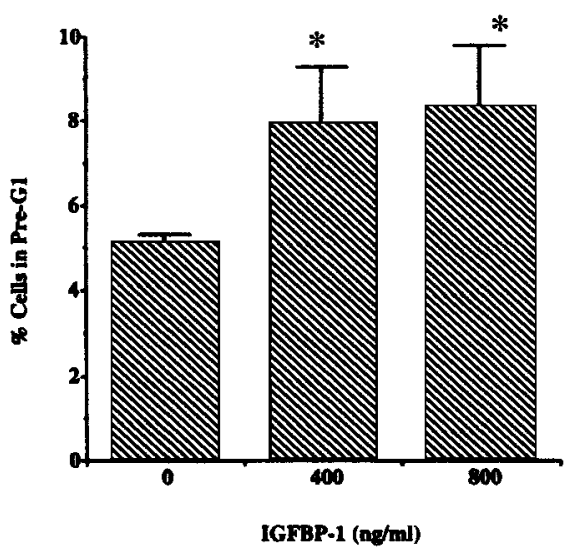

C

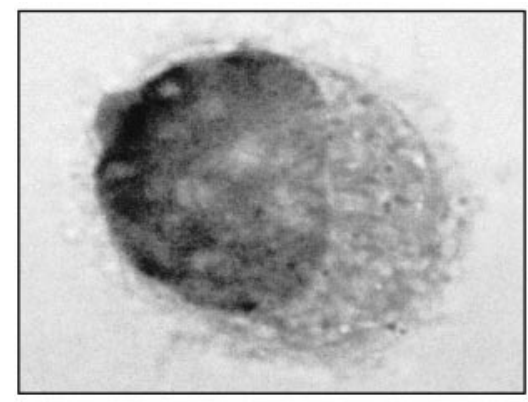

D

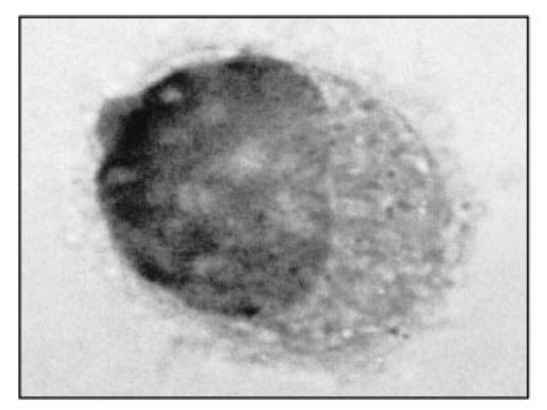

has been demonstrated conclusively to be specifically bound by IGFBP-1 (Jones et al. 1993). The antibody to the $\beta_{1}$ subunit identified the membrane-associated region and the anti- $\alpha_{5}$ recognised the cytoplasmic domain of this integrin in both cell lines (Fig. 5A-C).

\section{DISCUSSION}

It was originally believed that the integrins were a family of receptors which simply allowed cells to adhere to the ECM. However, it is becoming increasingly evident that they can transmit signals regulating cell growth, differentiation and death.

In this study we have shown that treatment of human breast cancer cells, T47D and Hs578T, with a synthetic RGD-containing peptide or with IGFBP-1 resulted in FAK dephosphorylation after 30 min and subsequent cell detachment and death by apoptosis after $24 \mathrm{~h}$. FAK is thought to play a key role in integrin-mediated signal transduction pathways (Zachary \& Rozengurt 1992). FAK phosphorylation is increased by integrin-mediated cell adhesion, for example when platelets (Lipfert et al. 1992) or benign and malignant cells attach to fibronectin (Guan \& Shalloway 1992). Clustering of $\beta 1$ and $\beta 3$ integrins also induces the phosphorylation of FAK (Guan et al. 1991, Kornberg et al. 1991). In addition, extracellular agents, including platelet-derived growth factor (Rankin \& Rozengurt 1994), bombesin or endothelin (Zachary et al. 1992), have also been shown to induce FAK phosphorylation in Swiss 3T3 cells.

The complete deletion of FAK causes a marked reduction in cell motility (Illic et al. 1995). Conversely, the overexpression of FAK is associated with increased cell motility as demonstrated by motile melanoma cells (Akasaka et al. 1995).

FIGURE 3. Measurement of apoptosis in T47D cells treated with a synthetic RGD-containing peptide (A) and IGFBP-1 (B) for $24 \mathrm{~h}$. Cells were grown in six-well plates, allowed to settle and switched to SFM for $24 \mathrm{~h}$ prior to treatment. Cells were then incubated with either (A) a synthetic RGD-containing peptide $(0-100 \mu \mathrm{g} / \mathrm{ml})$ or (B) IGFBP-1 $(0-800 \mathrm{ng} / \mathrm{ml})$ for a further $24 \mathrm{~h}$. Cells were analysed for apoptosis by flow cytometry as outlined in Materials and Methods. Results represent the mean \pm s.E.M. of three wells from experiments repeated at least three times. (C and D) Represent photomicrographs of control cells and those treated with $800 \mathrm{ng} / \mathrm{ml}$ IGFBP-1 respectively. Cells were cytospun and stained with Wright's stain in an automated stainer (Lillie 1977). Photomicrographs were taken under oil immersion at a magnification of $\times 100$. 


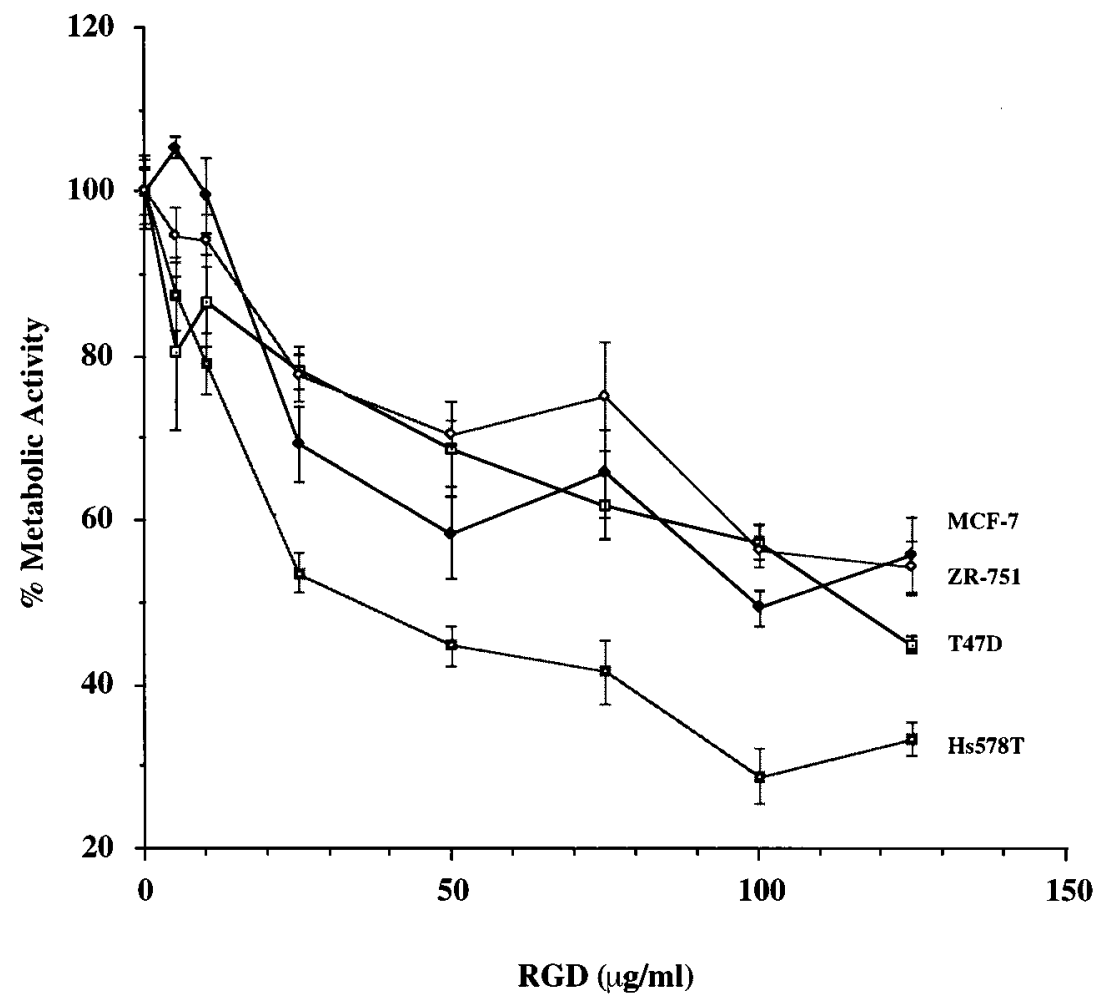

FIGURE 4. Addition of a synthetic RGD-containing peptide to human breast cancer cell lines. Cells were seeded in 96-well plates and all were switched to SFM prior to dosing with a synthetic RGD-containing peptide $(0-125 \mu \mathrm{g} / \mathrm{ml})$ for $24 \mathrm{~h}$. MTT activity was assayed as described under Materials and Methods. The results represent the mean \pm s.E.M. of five wells from one experiment which is representative of experiments repeated at least three times.

Furthermore, the invasive and metastatic phenotype in solid tumours has also been correlated with increased FAK expression (Owens et al. 1995).

In this paper we have demonstrated that a synthetic RGD-containing peptide and IGFBP-1 caused FAK to be dephosphorylated. Previous data have shown that generally FAK requires to be phosphorylated for subsequent effects to be elicited. However, one paper did report the dephosphorylation of FAK by insulin in HIRc cells (Pillay et al. 1995) although its functional significance at that time was unknown. In our model the dephosphorylation of FAK after $30 \mathrm{~min}$ was followed by subsequent cell detachment and deletion by apoptosis. As with other acute signalling events, the link with subsequent changes in cell function remains to be proven.

Apoptosis is a highly regulated mode of cell death which is characterised by a number of morphological and biochemical features including cell blebbing of the plasma membrane, cell shrinkage, chromatin condensation and DNA fragmentation into membrane-bound vesicles (Wyllie 1980). This process allows harmful, redundant or abnormal cells to be removed without harm to the organism. It allows a balance between cell proliferation and death ensuring homeostasis in a multicellular organism. However, dysregulation of apoptosis can lead to the emergence of many diseases including AIDS and neurodegenerative disorders where apoptosis is upregulated, and cancer where it is inhibited (Thompson 1995).

Our results show that IGFBP-1 has the ability to induce cell detachment in both the Hs578T and T47D cell lines and the degree of detachment was much greater in the T47Ds in comparison to the Hs578T cells. This could reflect that each cell line possesses a different complement of integrin receptors, varying in both type and number. This is further highlighted by the differential dosedependent effects of the synthetic RGD-containing peptide in the different breast cancer cell lines. 
$\mathbf{A}$

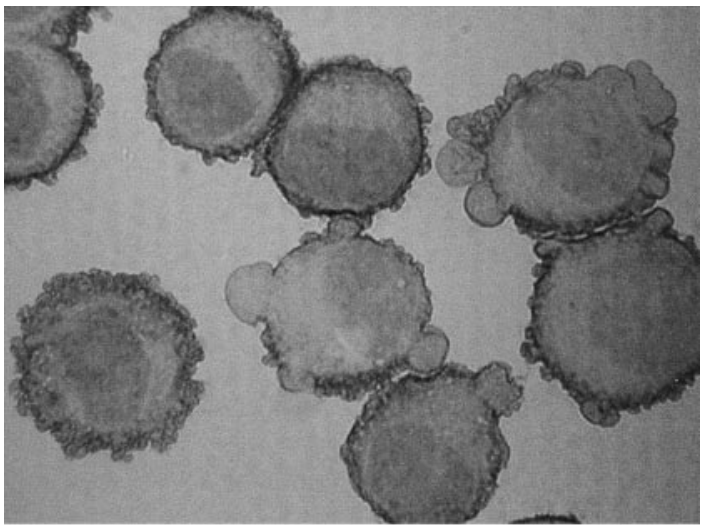

B
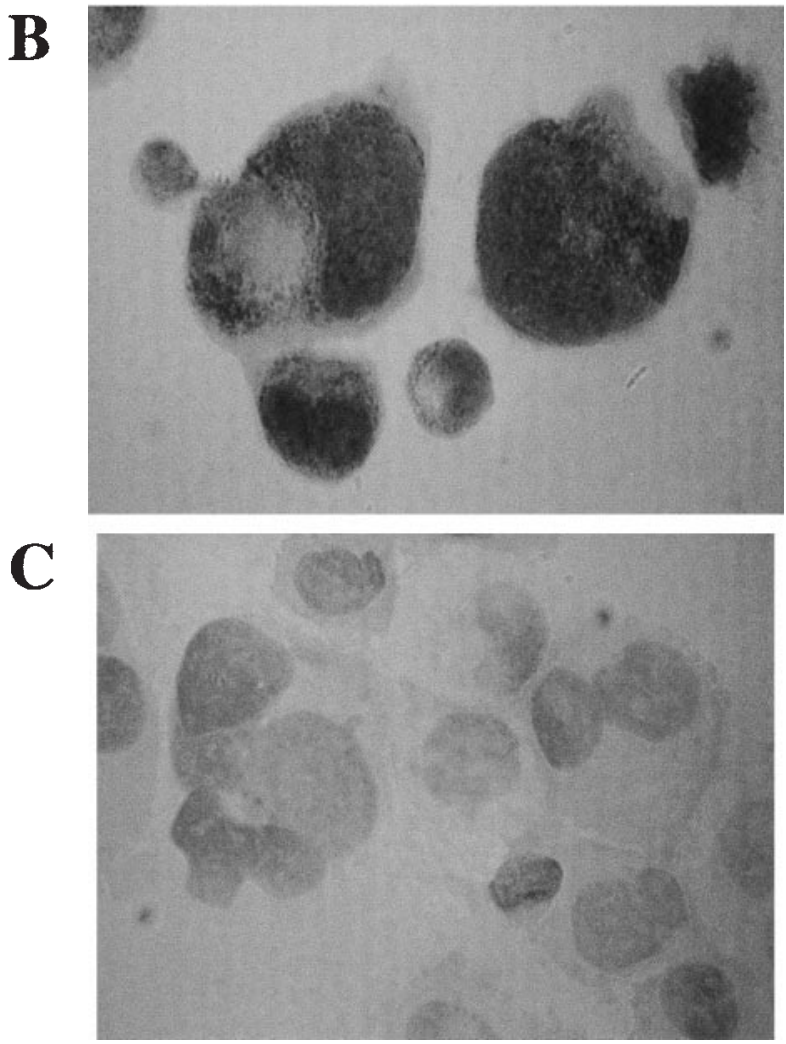

FIGURE 5. Localisation of $\beta_{1}$ and $\alpha_{5}$ integrin subunits by immunocytochemistry on cytospins of T47D cells. (A and B) Represent cells stained for $\beta_{1}$ and $\alpha_{5}$ integrin subunits respectively with (C) as the negative control. Cells were processed for immunocytochemistry as outlined in Materials and Methods. Photomicrographs were taken under oil immersion at a magnification of $\times 100$.

We have demonstrated previously that Hs578T cells have no functional type I IGF receptors and cannot be rescued by IGF-I from ceramide-induced apoptosis (Gill et al. 1997). These data provide evidence that the induction of apoptosis $24 \mathrm{~h}$ after
IGFBP-1 treatment described in this cell line is therefore independent of IGF-I. The rates of cell detachment and subsequent apoptosis in this cell line are also fairly comparable. In contrast, T47D cells showed high rates of cell detachment which were followed by comparably lower rates of apoptosis. These data suggest that a large proportion of the T47D cells which have been detached from the plate by both RGD and IGFBP-1 are still alive due to IGF-mediated cell survival. Therefore, the amount of apoptosis we have found in the T47D cell line, induced by RGD and IGFBP-1, is likely to be underestimated.

Finally, the higher rates of cell death induced by RGD in the Hs578 $\mathrm{T}$ in comparison to the T47D cells were corroborated by the MTT assay, which is a crude measure of cell survival. These data confirmed that the Hs578T cells were the most sensitive to RGD-induced apoptosis. In addition, they illustrated that all the different cell lines responded differently to RGD, which was probably dependent on their respective complement of integrin receptors.

IGF-independent effects of IGFBP-1 could have particularly important physiological implications in the body, where it is expressed. The IGF system is thought to mediate steroid hormone actions in both the ovary and endometrium. The biological effects of the IGFs within the endometrium are modulated by specific binding proteins which can inhibit or enhance effects at the cellular level (Rutanen et al. 1994). It has been shown that IGFBP-1 is expressed in the endometrium only during the secretory phase of the menstrual cycle (Zhou et al. 1994), which is associated with an upregulation of apoptosis. Interestingly, in endometrial cancer the expression of IGFBP-1 is suppressed with no cyclic variation (Rutanen et al. 1994). We have demonstrated that IGFBP-1 can induce apoptosis independently of IGFs. Therefore, in the normal cycle during the secretory phase IGFBP-1 could be contributing to the increased rate of apoptosis required for tissue remodelling. The downregulation of IGFBP-1 which occurs in endometrial cancer could cause an imbalance between cell growth and death.

IGF-independent effects of IGFBP-1 could also play a role in the process of cytotrophoblast invasion. Trophoblasts upregulate $\alpha_{5} \beta_{1}$ receptors as they invade decidual ECM matrix (Damsky et al. 1992). IGFBP-1 is localised in stromal cells and the ECM of the maternal decidua (Rutanen et al. 1984). Therefore, IGFBP-1 is present at the maternal-foetal interface, which may suggest that it could bind to the $\alpha_{5} \beta_{1}$ receptor on the trophoblast and regulate its invasion into the maternal decidua. 
In summary, we have demonstrated that IGFBP-1 and a synthetic RGD-containing peptide can induce FAK dephosphorylation after $30 \mathrm{~min}$ with subsequent cell detachment and death by apoptosis. Furthermore, these data suggest that IGFBP-1 has the ability to evoke integrin-mediated IGF-independent effects in vivo.

\section{ACKNOWLEDGEMENTS}

We wish to thank the UK Medical Research Council and Zeneca Pharmaceuticals for financial support and would also like to thank Eser Kilic for his help with the measurement of focal adhesion kinase.

\section{REFERENCES}

Akasaka T, van Leeuwen IG, Yoshinaga IG, Mihm MC \& Byers HR 1995 Focal adhesion kinase (p125 $\left.{ }^{\mathrm{FAK}}\right)$ expression correlates with motility of human melanoma cell lines. Fournal of Investigative Dermatology 105 104-108.

Bockholt SM \& Burridge K 1993 Cell spreading on extracellular matrix proteins induces tyrosine phosphorylation of tensin. Fournal of Biological Chemistry 268 14565-14567.

Brewer MT, Stetler GL, Squires CH, Thompson RC, Busby WH \& Clemmons DR 1988 Cloning, characterization and expression of a human insulin-like growth factor binding protein. Biochemical and Biophysical Research Communications 152 1289-1297.

Burridge K, Fath K, Kelly T, Nuckolls G \& Turner C 1988 Focal adhesions: transmembrane junctions between the extracellular matrix and the cytoskeleton. Annual Review of Cell and Developmental Biology 4 487-525.

Burridge K, Turner CE \& Romer LH 1992 Tyrosine phosphorylation of paxillin pp $125^{\mathrm{FAK}}$ accompanies cell adhesion to extracellular matrix: a role in cytoskeletal assembly. Fournal of Cell Biology 119 893-903.

Clemmons DR 1992 IGF binding proteins: regulation of cellular actions. Growth Regulation 2 80-87.

Clemmons DR, Camacho-Hubner C, Coronado E \& Osborne CK 1990 Insulin-like growth factor binding protein secretion by breast carcinoma cell lines: correlation with estrogen receptor status. Endocrinology 127 2679-2686.

Damsky CH, Fitzgerald ML \& Fisher SJ 1992 Distribution patterns of extracellular matrix components and adhesion receptors are intricately modulated during first trimester cytotrophoblastic differentiation along the invasive pathway, in vivo. Fournal of Clinical Investigation 89 210-222.

Freedman VH \& Shin S 1974 Cellular tumorigenicity in nude mice: correlation with cell growth in semisolid medium. Cell $3353-359$.

Frisch SM \& Francis H 1994 Disruption of epithelial cell-matrix interactions induces apoptosis. Fournal of Cell Biology 124 619-626.

Giancotti FG \& Ruoslahti E 1990 Elevated levels of $\alpha_{5} \beta_{1}$, fibronectin receptor suppress the transformed phenotype of CHO cells. Cell 60 849-859.

Gill ZP, Perks CM, Newcomb PV \& Holly JMP 1997 Insulin-like growth factor binding protein (IGFBP-3) predisposes breast cancer cells to programmed cell death in a
non-IGF dependent manner. Fournal of Biological Chemistry 272 25602-25607.

Guan JL \& Shalloway D 1992 Regulation of pp125 $5^{\text {FAK }}$ both by cellular adhesion and by oncogenic transformation. Nature 358 690-692.

Guan JL, Trevithick JE \& Hynes RO 1991 Fibronectin/ integrin interaction induces tyrosine phosphorylation of a 120-kDa protein. Cell Regulation 2 951-964.

Hayman EG, Pierschbacher MD \& Ruoslahti E 1985 Detachment of cells from culture substrate by soluble fibronectin peptides. Fournal of Cell Biology 100 1948-1954.

Hynes RO 1992 Integrins: versatility, modulation and signalling in cell adhesion. Cell 69 11-25.

Illic D, Furuta Y, Kanazawa S, Takeda N, Sobue K, Nakatsuji N, Nomura S, Fujimoto, Okada M, Yamamoto T \& Aizawa S 1995 Reduced cell motility and enhanced focal adhesion contact formation in cells from FAK-deficient mice. Nature 377 539-544.

Ingber DE 1990 Fibronectin controls capillary endothelial cell growth based on its ability to modulate cell shape. Proceedings of the National Academy of Sciences of the USA 87 3579-3583.

Jones JI, Gockerman A, Busby WH \& Clemmons DR 1993 IGFBP-1 stimulates cell migration and binds to the $\alpha_{5} \beta_{1}$ integrin by means of its Arg-Gly-Asp sequence. Proceedings of the National Academy of Sciences of the USA 90 10553-10557.

Julkunen M, Koistinen R, Aalto-Setölö K, Seppölö M, Jönne OA \& Kontula K 1988 Primary structure of human insulin-like growth factor binding protein/placental protein 12 and tissue-specific expression of its mRNA. FEBS Letters $236295-302$.

Knudson KA, Rao PE, Damsky CH \& Buck CA 1981 Membrane glycoproteins involved in cell-substratum interactions. Proceedings of the National Academy of Sciences of the USA 78 6071-6075.

Kornberg LJ, Earp HS, Turner CE, Prockop C \& Juliano RL 1991 Signal transduction by integrins: increased protein tyrosine phosphorylation caused by integrin clustering. Proceedings of the National Academy of Sciences of the USA 88 8392-8396.

Lillie RD 1977 HY Conn's Biological Stains, edn 9. Baltimore, USA: Williams and Wilkins Company.

Lipfert L, Haimovitch B, Schaller MD, Cobb BS, Parsons JT \& Brugge JS 1992 Integrin dependent phosphorylation and activation of the protein tyrosine kinase pp125 12 FA in platelets. Fournal of Cell Biology 119 905-912.

Mohn KL, Melby AE, Tewari DS, Laz TM \& Taub R 1991 The gene encoding rat insulin-like growth factor binding protein-1 is rapidly and highly induced in regenerating liver. Molecular and Cellular Biology 11 1393-1401.

Oh Y, Nagalla SR, Yamanaka Y, Kim HS, Wilson E \& Rosenfeld RG 1996 Synthesis and characterisation of insulin-like growth factor-binding protein (IGFBP)-7. Fournal of Biological Chemistry 271 30322-30325.

Owens LV, Hu L, Craven RJ, Dent GA, Weiner TM, Kornberg L, Liu ET \& Cance WG 1995 Overexpression of focal adhesion kinase $\left(\mathrm{p} 125^{\mathrm{FAK}}\right)$ in invasive human tumours. Cancer Research 55 2752-2755.

Pekonen F, Nyman T, Ilvesmöki V \& Partanen S 1992 Insulin-like growth factor binding proteins in human breast cancer tissue. Cancer Research 52 5204-5207.

Pierschbacher MD \& Ruoslahti E 1984 Cell attachment activity of fibronectin can be duplicated by small synthetic fragments of the molecule. Nature 309 30-33.

Pillay TS, Sasaoka T \& Olefsky JM 1995 Insulin stimulates the tyrosine dephosphorylation of pp125 focal adhesion kinase. Fournal of Biological Chemistry 270 991-994. 
Rankin S \& Rozengurt E 1994 Platelet-derived growth factor modulation of focal adhesion kinase $\left(\mathrm{p} 125^{\mathrm{FAK}}\right)$ and paxillin tyrosine phosphorylation in Swiss 3T3 cells. Fournal of Biological Chemistry 269 704-710.

Ruoslahti E \& Pierschbacher MD 1987 New perspectives in cell adhesion. Science 238 491-497.

Rutanen EM, Koistinen R, Wahlstrom T, Sjoberg J, Stenman UH \& Seppala M 1984 Placental protein 12 (PP12) in the human endometrium: tissue concentration in relation to histology and serum levels of PP12, progesterone and oestradiol. British Fournal of Obstetrics and Gynaecology 91 377-381.

Rutanen EM, Nyman T, Lehtovirta P, Ammala M \& Pekonen F 1994 Suppressed expression of insulin-like growth factor binding protein-1 messenger RNA in the endometrium - a molecular mechanism associating endometrial cancer with its risk factors. International Fournal of Cancer 59 307-312.

Shimasaki S, Shimonaka M, Zhang HP \& Ling N 1991 Identification of five different insulin-like growth factor binding proteins (IGFBPs) from adult rat serum and molecular cloning of a novel IGFBP-5 in rat and human. Fournal of Biological Chemistry 266 10646-10653.

Suikkari AM, Jalkanen J, Koistinen R, Bützow R, Ritvos O, Ranta T \& Seppölö M 1989 Human granulosa cells synthesize low molecular weight insulin-like growth factor-binding protein. Endocrinology 124 1088-1099.

Thompson CB 1995 Apoptosis in the pathogenesis and treatment of disease. Science 267 1456-1462.

Tucker RW, Butterfield CE \& Folkman J 1981 Interaction of serum and cell spreading affects growth of neoplastic and nonneoplastic cells. Fournal of Supramolecular Structure 15 $29-40$.

Wyllie AH 1980 Cell death: the significance of apoptosis. International Review of Cytology 60 251-306.

Zachary I \& Rozengurt E 1992 Focal adhesion kinase $\left(\mathrm{p} 125^{\mathrm{FAK}}\right)$ : a point of convergence in the action of neuropeptides, integrins and oncogenes. Cell $\mathbf{7 1}$ 891-894.

Zachary I, Sinnett-Smith J \& Rozengurt E 1992 Bombesin, vasopressin and endothelin stimulation of tyrosine phosphorylation in Swiss 3T3 cells. Fournal of Biological Chemistry 267 19031-19034.

Zhou J, Dsupin BA, Giudice LC \& Bondy CA 1994 Insulin-like growth-factor system gene expression in human endometrium during the menstrual cycle. Fournal of Clinical Endocrinology and Metabolism 79 1723-1734.

REVISED MANUSCRIPT RECEIVED 30 September 1998 